\title{
PENGARUH PENERAPAN PSAK 2 (LAPORAN ARUS KAS) TERHADAP INDIKATOR KEPUTUSAN INVESTASI PADA PT GOODYEAR TBK TAHUN 2009-2013
}

\author{
Akhsanul Haq \\ Dosen Tetap Fakultas Ekonomi Universitas Pakuan \\ Lecturer of Economic Faculty at Pakuan University \\ Hariza Camelia \\ Mahasiswa Fakultas Ekonomi Universitas Pakuan \\ Student of Economic Faculty at Pakuan University
}

\begin{abstract}
ABSTRAK
Parameter kinerja perusahaan yang mendapat perhatian utama dari investor dan kreditor dari laporan keuangan adalah laba dan arus kas. Para investor memiliki harapan bahwa dengan melakukan investasi akan memperoleh return baik dalam bentuk dividen yang besarnya minimal sama dengan tingkat bunga deposito, ataupun dalam bentuk capital gain, yaitu dari hasil harga jual dan harga beli. Tujuan penelitian ini dilakukan adalah untuk mengetahui pengaruh laporan arus kas (PSAK 2) terhadap keputusan investasi oleh investor pada PT Goodyear Tbk periode 2009-2013. Metode penelitian yang digunakan adalah metode studi kasus dan teknik analisis data menggunakan metode rasio keuangan. Hasil dari penelitian ini menunjukkan bahwa laporan arus kas dapat digunakan sebagai indikator keputusan investasi dalam perusahaan. Dengan menggunakan rasio-rasio keuangan dan menggunakan perbandingan rasio keuangan laporan keuangan arus kas. Hasil penelitian menilai bahwa terdapat indikasi nilai dimana rasio-rasio keuangan yang digunakan sebagai penilaian terhadap indikasi keputusan investasi yaitu lebih dari -1 dan kurang dari +1 .
\end{abstract}

Kata Kunci : Laporan Arus Kas (PSAK 2), Indikator Keputusan Investasi

\section{ABSTRACT}

Parameters company performance is a major concern of investors and creditors of financial statements is profit and cash flow. Investors have hopes that by making the investment, it's will earn a return in the form of dividends in the amount at least equal to the interest rate on deposits, or form of capital gains, it is the results of the sale price and purchase price. The purpose of this research was to determine the effect of cash flow statement (PSAK 2) for investment decisions by investors in PT Goodyear, Tbk 20092013 period. The method used was the case study method and technique of data analysis using financial ratios. Results from this study indicate that the cash flow statement can be used as an indicator of the company's investment decisions. By using financial ratios and use of comparative financial ratios financial statements of cash flows. Results of the study considers that there are indications that the value of financial ratios are used as an indication of the assessment of the investment decisions of more than -1 and less than +1 .

Keywords: Cash Flow Statements (PSAK 2), Indicator Investment Decision

\section{Pendahuluan}

Persaingan dunia bisnis di Indonesua saat ini sangatlah ketat. Berbagai jenis perusahaan bermunculan yang bergerak di bidang yang berbedabeda seperti bidang jasa, manufaktur, maupun dagang yang saling bersaing untuk dapat bertahan dan menjadi yang terbaik, hal ini mendorong masing- masing perusahaan untuk melakukan berbagai strategi agar terhindar dari kesulitan keuangan. Salah satu alat ukur dari kesulitan keuangan adalah arus kas keuangan, hal ini dapat dilihat pada laporan arus kas yang diatur oleh PSAK No. 2.

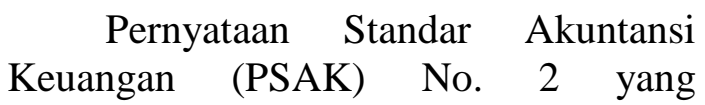


menyatakan perusahaan harus menyusun laporan arus kas dan menyajikan laporan tersebut sebagai bagian yang tak terpisahkan dari laporan keuangan. Parameter kinerja perusahaan yang mendapat perhaian utama dari investor dan kreditor dari laporan keuangan adalah laba dan arus kas.

Para investor memiliki harapan bahwa dengan melakukan investasi akan memperoleh return baik dalam bentuk deviden ataupun dalam bentuk capital gain. Dengan resiko yang rendah dan return yang stabil inilah yang menentukan preferensi para investor. Resiko (risk) dan return merupakan indikator yang diperhitungkan oleh para investor dalam analisis investasinya. Untuk melakukan interprestasi atau analisis kinerja keuangan khususnya untuk pusat pertanggungjawaban investasi, diperlukan tolak ukur tertentu.

PT Goodyear Tbk. merupakan salah satu perusahaan yang konsisten dan tetap pada prosedur dalam memenuhi modal investasi terhadap para investor. Hal tersebut terlihat dari meningkatnya pengeluaran kas untuk pembayaran deviden kas setiap tahunnya.

Oleh karena itu tujuan penelitian ini dilakukan adalah 1) untuk mengetahui bagaimana keputusan investasi oleh investor pada PT Goodyear Tbk periode 2009-2013. 2) untuk mengetahui pengaruh laporan arus kas (PSAK 2) terhadap keputusan investasi oleh investor pada PT Goodyear Tbk periode 2009 - 2013.

\section{Metode Penelitian}

Metode penelitian yang digunakan penulis adalah metode penelitian korelasi atau korelasional untuk mengetahui hubungan dan tingkat hubungan antara dua variabel atau lebih.

\section{Hasil dan Pembahasan}

3.1. Laporan Arus Kas (PSAK 2)

Dalam penelitian ini penulis menggunakan laporan keuangan PT Goodyear Tbk periode 2009-2013, yang mencakup neraca, laporan laba rugi dan laporan arus kas.

Tabel 3.1.

Informasi Keuangan PT Goodyear Tbk periode 2009-2013

Information of Financial PT Goodyear Tbk 2009-2013

\begin{tabular}{|l|l|l|l|l|l|l|}
\hline No & \multicolumn{1}{|c|}{ Keterangan } & \multicolumn{1}{|c|}{2009} & 2010 & 2011 & 2012 & 2013 \\
\hline 1 & $\begin{array}{l}\text { Arus Kas } \\
\text { Operasi }\end{array}$ & 37.448 .724 & 19.523 .485 & 16.294 .712 & 13.992 .822 & 18.862 .318 \\
\hline 2 & $\begin{array}{l}\text { Cakupan Arus } \\
\text { Dana }\end{array}$ & -9.912 .849 & -7.637 .699 & -9.657 .170 & -9.600 .044 & -7.695 .820 \\
\hline 3 & $\begin{array}{l}\text { Kewajiban } \\
\text { Lancar }\end{array}$ & 55.915 .968 & 67.331 .761 & 76.667 .805 & 69.464 .592 & 53.178 .435 \\
\hline 4 & $\begin{array}{l}\text { Pengeluaran } \\
\text { Modal }\end{array}$ & -34.230 .670 & -9.110 .018 & -6.375 .074 & -7.802 .643 & -10.550 .967 \\
\hline 5 & $\begin{array}{l}\text { Laba Sebelum } \\
\text { Pajak }\end{array}$ & 16.283 .766 & 8.620 .427 & 3.130 .124 & 9.100 .459 & 6.643 .543 \\
\hline 6 & $\begin{array}{l}\text { Laba Setelah } \\
\text { Pajak }\end{array}$ & 11.645 .100 & 7.415 .868 & 2.156 .464 & 6.673 .997 & 4.634 .391 \\
\hline 7 & Total Ekuitas & 39.795 .087 & 46.223 .880 & 47.175 .595 & 52.730 .292 & 56.225 .906 \\
\hline 8 & $\begin{array}{l}\text { Total } \\
\text { Kewajiban }\end{array}$ & 76.043 .707 & 81.461 .205 & 83.626 .715 & 71.185 .039 & 54.822 .258 \\
\hline 9 & Pembayaran & -236.584 & -987.075 & -1.024 .749 & -1.115 .494 & -1.145 .242 \\
\hline
\end{tabular}

JIAFE (Jurnal Ilmiah Akuntansi Fakultas Ekonomi)

Volume 1 No. 1 Tahun 2015, Hal. 10-14 


\section{Deviden Kas}

Dari tabel diatas dapat terlihat beberapa pos keuangan mengalami fluktuasi. Tahun 2009-2013 pos keuangan pembayaran devisen kas perusahaan terus mengalami peningkatatan pengeluaran setiap tahunnya, hal ini menunjukkan bahwa perusahaan konsistem dalam memenuhi modal investasi terhadap para investor berupa deviden kas.

\subsection{Pengaruh Laporan Arus Kas Terhadap Keputusan Investasi}

Tabel 3.2.

Pengaruh Laporan Arus Kas Terhadap Keputusan Investasi periode 2009-2013

PT Goodyear Tbk Effect of Cash Flow Statement to Investment Decisions 2009-2013 period PT Goodyear Tbk

\begin{tabular}{|l|c|l|l|l|l|l|}
\hline No & Keterangan & 2009 & 2010 & 2011 & 2012 & 2013 \\
\hline 1 & $\frac{\text { Total Kewajiban }}{\text { Ekuitas Pemegang Saham }}$ & 0.97 & 1.04 & 1.07 & 0.91 & 0.70 \\
\hline 2 & $\frac{\text { Laba Bersih }}{\text { Total Asset }}$ & 0.10 & 0.06 & 0.02 & 0.05 & 0.04 \\
\hline 3 & $\frac{\text { Laba Bersih }}{\text { Total Ekuitas }}$ & 0.29 & 0.16 & 0.05 & 0.13 & 0.08 \\
\hline 4 & $\frac{\text { Kas dan Setara Kas }}{\text { Hutang Lancar }}$ & 0.17 & 0.19 & 0.17 & 0.13 & 0.15 \\
\hline
\end{tabular}

\subsection{Hasil Perhitungan Rasio Keuangan}

Tabel 3.3.

Hasil Perhitungan Berdasar data keuangan PT Goodyear Tbk periode 2009-2013 Calculation Result of Calculation Based on the financial data of PT Goodyear Tbk 2009-2013

\begin{tabular}{|l|l|l|l|l|l|l|}
\hline No & Keterangan & 2009 & 2010 & 2011 & 2012 & 2013 \\
\hline 1 & Rasio Kas Operasi & 0.67 & 0.29 & 0.21 & 0.20 & 0.35 \\
\hline 2 & Rasio Cakupan Dana & -1.64 & -1.13 & -0.32 & -0.95 & -0.86 \\
\hline 3 & Rasio Total Hutang & 0.49 & 0.24 & 0.19 & 0.20 & 0.34 \\
\hline 4 & Rasio Cakupan Kas HL & 0.67 & 0.28 & 0.20 & 0.19 & 0.33 \\
\hline 5 & Rasio Pengeluaran Modal & -1.09 & -2.14 & -2.56 & -1.79 & -1.79 \\
\hline 6 & ROE & 0.29 & 0.16 & 0.05 & 0.13 & 0.08 \\
\hline
\end{tabular}

\subsection{Analisis Perusahaan Terhadap Investasi}

Laporan Keuangan yang disajikan dan dilaporkan oleh perusahaan setiap periode memberikan gambaran secara umum perusahaan dalam mengelola sumber daya keuangan dan kinerja keuangannya. Laporan keuangan yang dihasilkan berupa neraca, laporan laba rugi, dan laporan arus kas, masingmasing memberikan gambaran tersendiri 
berdasarkan fungsi yang dimiliki oleh laporan keuangan tersebut.

Berdasarkan perhitungan rasiorasio keuangan diatas perusahaan memiliki prospek positif dan memiliki nilai investasi yang bagus dimasa yang akan datang ditinjau dari laporan keuangan tahun 2009-2013. Terbukti dengan nilai Return Of Equity (ROE) memiliki nilai kurang dari +1 dan lebih dari -1

\section{Simpulan}

Berdasarkan hasil penelitian dan pembahasan yang telah dilakukan, maka dapat ditarik kesimpulan sebagai berikut

1. Dalam hal ini PT Goodyear Tbk, dalam menyajikan dan mempublikasikan laporan keuangan baik berupa laporan neraca, laporan laba rugi serta laporan arus kas pada tahun 20092013 secara wajar dan sesuai dengan ketentuan standar akuntansi keuangan yang berlaku secara umum.

2. Laporan keuangan yang terdiri dari laporan neraca, laporan laba rugi serta laporan arus kas yang merupakan indikator utama dalam melakukan evaluasi investor atau kreditur dalam melakukan tindakan keputusan investasi kepada perusahaan, dimana dalam hal ini PT Goodyear Tbk merupakan objek dari keputusan investasi itu sendiri. Sehingga peranan laporan keuangan dalam mengambil suatu tindakan keputusan investasi sangat diperlukan, karena laporan keuangan berfungsi sebagai alat dalam penggambaran suatu perusahaan. Dalam konteks ini laporan arus kas yang sangat memiliki peranan aktif dalam pengambilan keputusan investasi oleh investor kepada perusahaan.

3. Laporan arus kas memiliki keterkaitan datau memilki korelasi dalam pengambilan suatu keputusan investasi, selain itu laporan keuangan berupa laporan neraca dan laporan laba rugi juga berfungsi sebagai alat dalam membantu menggambarkan kondisi keuangan serta kinerja perusahaan. Indikator yang digunakan dalam analisa keputusan investasi itu diperoleh dari rasio laporan kas meliputi rasio cakupan dana (RCD), rasio kas operasi (RKO), rasio cakupan arus kas terhadap hutang lancar (CKHL), rasio total hutang (TH), rasio pengeluaran modal (PM), return of equity (ROE). Sehingga laporan arus kas yang disajikan dan dilaporkan oleh PT Goodyear Tbk memiliki keterkaitan atau korelasional terhadap keputusan investasi oleh investor tahun 20092013.

\section{Daftar Pustaka}

Brigham, Eugene dan Joel F. Houston. 2001. Dasar-Dasar Manajemen Keuangan. Edisi Kesepuluh. Jakarta: Salemba Empat

Darsono dan Ashari. 2009. Pedoman Praktis Memahami Laporan Keuangan. Semarang : Penerbit Andi

Eduardus Tandelilin.2007. Analisis Investasi dan Manajemen. Portofolio (Edisi Pertama. Cetakan Kedua). Yogyakarta BPFE.

Gany Ibraim Fenandar. 2012. Pengaruh Keputusan Investasi, Keputusan Pendanaan, dan Kebijakan Deviden Terhadap Nilai Perusahaan. Disertasi Program Strata-1 Universitas Diponegoro. Semarang. 
Hardian Hariono Sinaga. 2010. Analisis Pengaruh Total Arus Kas, Komponen Arus Kas, Laba Akuntansi Terhadap Return Saham. Disertasi Strata-1 Universitas Dipenogoro. Semarang

Irfan Fahmi. 2011. Analisis Laporan Keuangan. Alfabeta. Bandung

Kasmir. 2010. Analisis Laporan Keuangan. PT Raja Grafindo Persada.

Sofyan Syafhfri Harahap. 2009. Analisis Kritis Atas Laporan Keuangan. Edisi 11. PT Raja Grafindo Persada. Jakarta.

Sugiyono. 2010. Metode Penelitian Pendidikan (Pendekatan Kuantitatif, Kualitatif dan $R \& D)$. Alfabeta. Bandung. 